\title{
宮田又鉱山の廃さい処理について
}

$\begin{array}{lllll}\text { 正会員 縄 } & \text { 田 } & \text { 守 } & \text { 彦* }^{*} \\ \text { 正会員 } & \text { 正 } & \text { 田 } & \text { 秀 } & \text { 穗 }\end{array}$

\section{Tailing Disposal at Miyatamata Mine}

Morihiko NAWATA and Hideho HIKITA

The method of tailing disposal at Miyatamata Mine is a so-called "pile up" method. Pulp from the mill plant, 19\%solid, -200 mesh $50 \%$, flows by gravity in ditches which have been built on the preceding pile up sand terraces, and are paralled with the base dam. Deslimed sand in the ditches is shoveled up into border crests. When the ditches become shallow, the outside of border crest is conditioned in $14^{\circ}$ slope forming dam face.

Advantages of this method are as follows:

1) Low cost of construction of base dam.

2) Easy selection of dam situation.

3) Natural sizing of slime in ditches.

4) Sufficient inspection and good control of dam by laborers.

\section{1. 緒 言}

釷山におけるる鉣さいの処理は鉱害，用地選定， 建設費, 経費, 保守等の問題があり, 釷山経営上 にしめる地位はなおさりに出来ない。今後各鉱山 共に鉣さいたい積場の建設費は嵩んで行くもの之 推測されるが，宮田又鉱山に执いては搭石鉱さい たい積場建設基淮に則りながらも建設費が経済的 に守み，かつ用地の比較的求め易いたい積法とし て積み上げたい積法を採用し，過去 4 年間にわた り実施して来たのでい坛までの経緯と構築法の大 略后発表し参考に供せんとするむのである。

\section{2. 位置及び地形}

宫田又鉙山は秋田県仙北郡協和村宮田又にあ り, 奥羽本線羽後境駅より $12 \mathrm{~km}$ に位置し駅より 林用軌道が通じている。鉣さいたい積場は選鉣場 から沢に沿つて $500 \mathrm{~m}$ 上流にあり周囲は鍋倉山 (530m）を主峯とする， $400 \mathrm{~m}$ 前後の山に围まれてい る。そしてこれ等の地域は官有林で有名な秋田天然杉の 産地である。この附近は宮田又沢とその支流である鍋倉 沢幽び芦倉沢以外はすべて浅く小さな沢よりなく選鉱場 附近にはたい積場に選定出来る様な地形がない。また上 述の沢は本沢であるため借地が不可能である。現在の東 沢たい積場老使用するまで 2 力所も選鉱場近くの小さな

\footnotetext{
* 新庭㱉開発株式全社生產課長
}

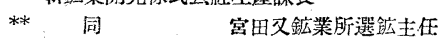

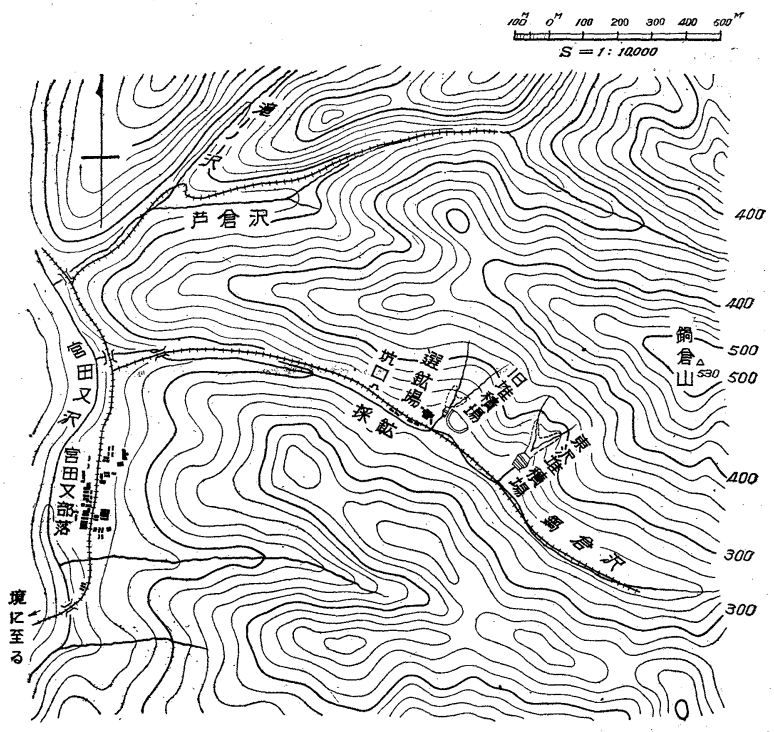

第 1 図 宮田又鉱山地形図

沢を堰止めて便用していたが，たい積量少なく合計 17,500tよりたい積出来なかつた。また現東沢たい積場 も普通のかん止堤を築造し，相当量のたい積を行うと思 えばいたずらに高さの高いかん止堤が必要となつて莫大 な建設費を要するが，これに積上げたい積法を採用守れ ば小額の建設費でしかも20万 t 以上のたい積を行い得る 地形である事が分つた。

3. 概 要 
本法はかつて鯛生金山を中心とした九州地方の金製錁 所廃さい处理に採用されて, 鯛生式揾上法と呼ばれてい たものを当鉱山で硫化物の浮選廃さい処理に適用し，積 雪に耐える様に工洷を改良したものである。金山との相 違は岩質では金山の变朽安山岩に対して当所は頁岩，凝 灰岩を主体とする第三紀水成岩であり，粒度は金山は細 粒であるが当所はー200 mesh 50\%の粗粒の鉣石を取扱 つている。これらの点を勘案して鯛生式とは幾分異なつ た方法夲行つている。

本工法は基礎堤と積み上げたい積部との二つの部分に 分れ，基礎是は普通のかん止堤と何等変りないかか高さを 低く取り基礎堤のみのたい積容量は小さくてもよい。 またたい積部の水分排除がよく行われるように石積かん 止堤が望ましいが当所は山土による土かん止堤である。

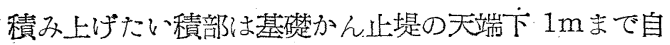
然たい積された鉣さい上に施行される。まず基礎堤に平 行な 2 本乃至 3 本の放泥水路を鉣さい上に造り，これに 選鉱場より送泥された鉣さい液を流し，水路中に沈港し た粗粒の砂を水路の両側にショベルで搔き上げて水路の 保護とする。この作業を繰返し水路保護の砂盛りが所定 の高さになれば使用を中止し、たい積傾斜として定めら れた $14^{\circ}$ にならす。水路は基礎堤に近い側から便用し， 使用済となれば新たに上流側に水路を造る。このように して順次水路を上流側に移して行き積上げを進行させる ものである。

たい積量は基礎堤法先より垂直高 $50 \mathrm{~m}$ で $215,000 \mathrm{t}$ で 9 力年の寿命がある。

\section{4. 㬐 渠}

瞕渠は第 3 困に示す様な形状で，鉄筋は上蓋のみに入 れ，両壁及び底盤は配合 $1: 3: 6$ の無筋コンクワートで 造られている。上蓋には場内水の排水孔が設けられ，終 端は開口し暗渠の両側に止水壁を設け沢水を導入守る。 故に当初の瞕渠は場内水之沢水排除用の 2 つを兼ねてい る。

暗渠の流量はマンニングの公式によれば次のようにな る。

流水断面 $A=0.392 \mathrm{~m}^{2}$

潤辺長 $P=1.90 \mathrm{~m}$

動水半径 $R=\frac{A}{P}=2.063 \mathrm{~m}$

勾 配 $J=\frac{12.3}{100}=0.123$

流 速 $V=\frac{1}{n} \cdot R^{\frac{2}{3}} \cdot J^{\frac{1}{2}}=7.66 \mathrm{~m} / \mathrm{sec}$

$$
\text { ただし } n=0.016
$$

流水量 $Q=A \cdot V=3.003 \mathrm{~m}^{3} / \mathrm{sec}$

降雨強度 $50 \mathrm{~mm} / \mathrm{h}\left(1 \mathrm{~km}^{2}\right.$ 当り $\left.13.9 \mathrm{~m}^{3} / \mathrm{sec}\right)$

流出你数 $85 \%$

流域面積 $0.129 \mathrm{~km}^{2}$

故に集水面積内の流出水量 $Q_{1}=1.524 \mathrm{~m}^{3} / \mathrm{sec}$

降水による常時流水量 $\quad Q_{2}=0.02 \mathrm{~m}^{3} / \mathrm{sec}$

融雪時流水量

$Q_{3}=0.05 \mathrm{~m}^{3} / \mathrm{sec}$

選鉙用水

$Q_{4}=0.008 \mathrm{~m}^{3} / \mathrm{sec}$

合計最大流水量

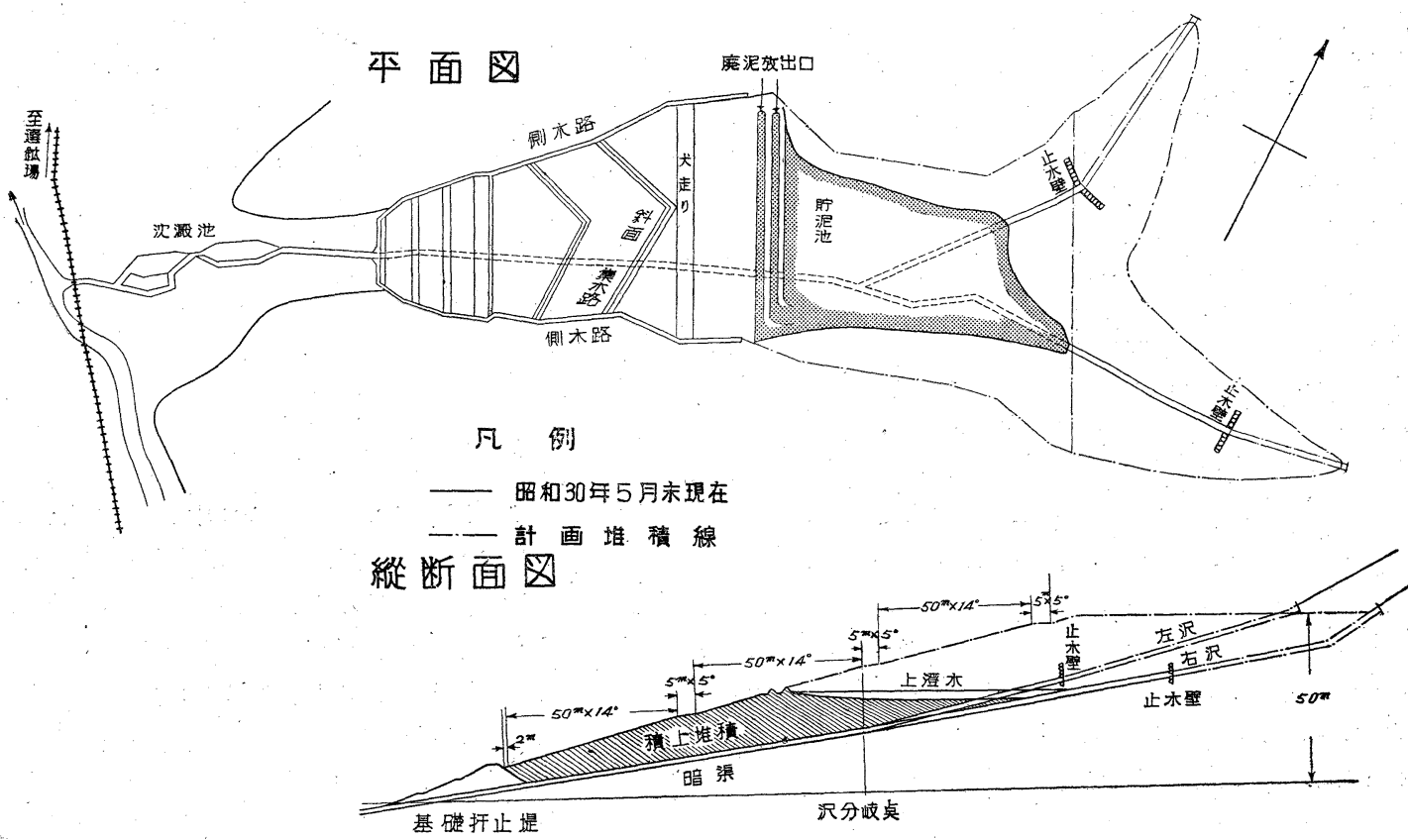

第2図東沢たい積場 

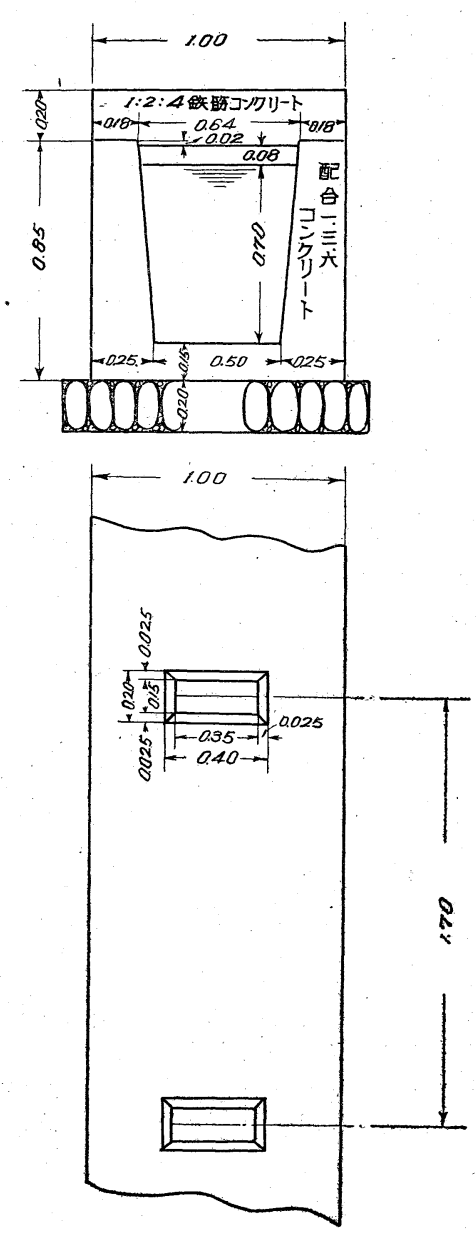

第 3 図 暗 渠

よつて暗渠流量 $3.003 \mathrm{~m}^{3} / \mathrm{sec}>$ 最大流水量 1.602 $\mathrm{m}^{3 / \mathrm{sce}}$

\section{5. 基礎汃儿止堤}

基礎かん止堤（基礎堤と呼ぶ）の構築材料は山土であ り, 高さ $10.5 \mathrm{~m}$, 長さ $40 \mathrm{~m}$, 天端巾 $4 \mathrm{~m}$, 外法面は 3 段 で各段に大走が造られ，勾配は下より1段 2 割，2段 2.5 割, 3 段 3 割である。内沠勾配は 1.7 割で石積であ る。

たい積場として理想的な條件は谷が梁く，傾敘が緩か
で，かん止堤構築個所の谷が狭まつている事であるが， 東沢たい積場はこの條件に当てはまらず沢の関係から基 礎堤が大きなものとなつた。第 4 区璂礎堤の緃断面で ある。

安定計算は円形滑面法を用い, 滑動半径 $30 \mathrm{~m}$ の場合 安全率最小となり $(m=1.65)$, 滑動半径 $50 \mathrm{~m}$ の場合安 全率最大となる $(m=2.35)$ 。

\section{6. 積み上げたい積施行法}

\section{1 積み上げたい積作業}

放流した鉱さいが基整堤天端より $1 \mathrm{~m}$ 下部天で自然沈 積されると次の段階として積み上げ作業にかかる。作業 はまず鉣さい放流口附近の砂の固まつた個所から導水路 を基礎堤に平行に造りこれを除々に延長して他端に達 せしめる。普通このようにして 2〜3 本の導水路を造り 交互に使用する。1 本の導水路が完成するのに約 1 力月 かかる。当所の場合導水路の直線部は $60 \mathrm{~m}$ でその先は 山岸に沿つて $20 \mathrm{~m}$ 上流に向つて導水路が延長している。 この程度の長さで粗粒の砂な導水路中に大体沈積され る。

導水路勾配は自然勾配であるが放流口に近い程粒子の 沈積量が多いので，放流口より対岸に向つて 1/50 1/60 程度の自然勾配がつく。鉣さい濃度は $19 \%$ 固体，粒度分 布は第 1 表の通りである。導水路の币は流速之水路両岸 に与える影響が大きく，余り狭いと流速がつき鉣粒の沈 降が悪くなり，かつ水路を破損し易く，その補修に手数 がかかるので最低ウ 1 mは必要である。常に砂を両岸に 盛り上げて行くため水路は狭くなり易いので造り始めは 巾 $2 \mathrm{~m}$ 程度に取つてやる必要がある。水路維持のため作 業員は常に水路に大り，沈降砂を搔き上げ両岸の保持に 心掛けねばならない。所定の高さ汽水路が上昇すると，

第1表 鈗さい粒度分布

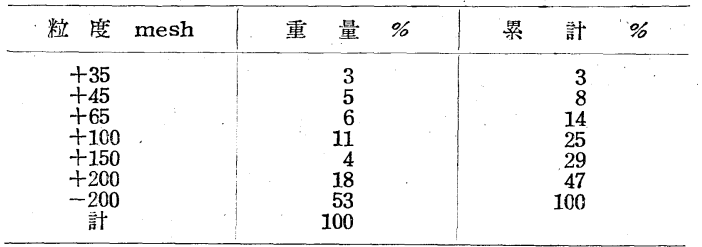

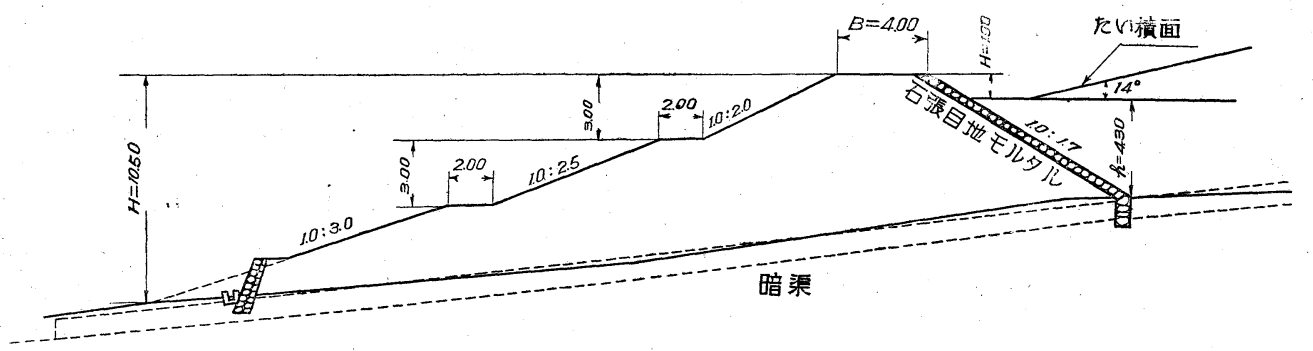

第4図基礎汃止堤縱断面図 
第 2表 水路任様 これを傾斜 $14^{\circ} に$ 搔さ均し積上

\begin{tabular}{|c|c|}
\hline 名 & 法 \\
\hline 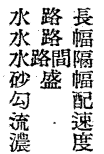 & $\begin{array}{c}80 \mathrm{~m} \\
1.8 \sim 1.0 \mathrm{~m} \\
5 \mathrm{~m} \\
1.5 \mathrm{~m} \\
1 / 50 \sim 1 / 60 \\
0.57 \mathrm{~m} / \mathrm{sec} \\
19 \% \text { 固体 }\end{array}$ \\
\hline
\end{tabular}

げたい積の斜面点形作つて行 く。1 本の導水路の寿命は約 3 カ月である。

第5园燇水路断面を示し， 第 2 表は水路の寸法，勾配等症 示高。

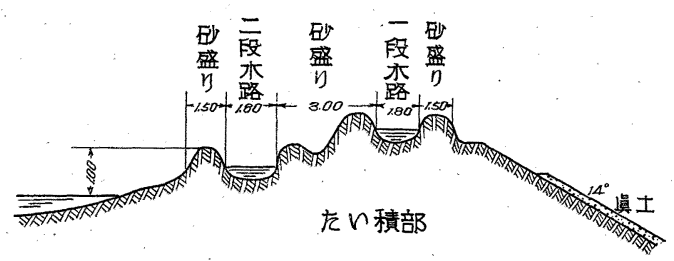

第5図 水路 断 面

\section{2 法 面 保 護}

$14^{\circ}$ の傾斜で積み上げられた砂上に山士を約 $20 \mathrm{~cm}$ 程 度の厚さで被覆し，これに雑草を植えて砂の流失を防ぐ のであるが周团に山土のない場合は本作羓は困難を伴 う。被覆用の土はたい積内部の水分蒸発炎妨げないよう な質のものがよい。亲た張芝用の草は根張りが強く，根 の周囲に水分夻留めないるのが適しており，松，杉等の 背伸びの方るものは強風の場合根に振動を与元地盤を弛 める恐れがある。

斜面集水路は第 6 図の如き形状をしたもの虎“へ”字 形に造り，降雨の場合斜面定流れる水を受止め, 真土流 失を防き， 雨水を側水路に導く役目をしており $25 \mathrm{~m}$ 間隔 に1本は是非造らねばならない。またたい積部の両側 地山に $0.6 \mathrm{~m} \times 0.6 \mathrm{~m}$ の練石積水路を積み上げの進行に従 い造亏。当所では半年に 1 回延長している。この水路は 非常溢水路と山腹承路を兼亦ている。

\section{3 冬期のたい積}

積雪地方では冬期のたい積に困難を伴うので当たい積

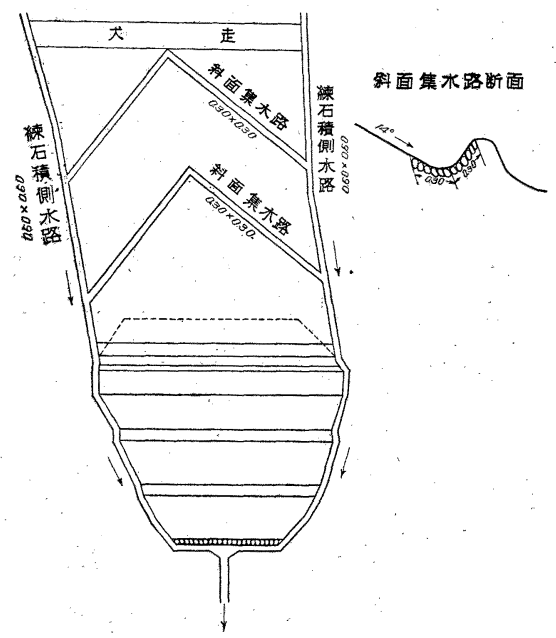

第 6 図

斜面集 水路及 び側水 路
法が九州地方の暖地に発達し，東北地方に発達しなかつ た理由もここにある。しかしながら $1 \mathrm{~m}$ 程度の積雪は大 きな障害とはならない。当鉱山附近で炤和30年度の最低 気温は $-8^{\circ} \mathrm{C}$, 積雪 $1.2 \mathrm{~m}$ であつたが，冬期を通じて使 用与ることが出来た。ただし積雪多量で常に吹雪が媓與来 す当地方では本方法は困難かと思われる。

当所の冬期の鉣さ、液温は放出口で $4^{\circ} \mathrm{C}$ 保つている ので，鉱さい液を通せば導水路中の雪は溶解し作業に支 障はない。水路両側の盛砂上の雪は常に掃き捨て根雪に ならないよう心脚ける事が必要である。承結した雪の上 に搔上砂なたい積すれば融雪期に崩壞する恐れがある。 したがつて公休日といえども降雪日は除雪人夫を就業せ 认め盛砂部の除雪を行うがよい。こうずれば冬期も順調 にたい積を行う事が出来る。しかしながら積雪のためダ 公傾斜が分らなくなるので積み上げたい積部の傾斜補正 と真土被覆は融雪後でないと行われない。

スラィム沈澱牠他の上澄水は時により氷結うる場合もあ つたが，暗渠溢流口附近の結氷を割る程度で特別な操作 は必要がなかった。

\section{7. 積上部の安定度}

\section{1 浸 潤 線}

たい積内部の飽和水線の測定には比抵抗法とソイルオ ーガーによる法と二通りを比較試験したがほとんぞ同数 值を得たのでここではソイルオーガーによる漫溜線測 定について述へる。

たい積部を縦横に $10 \mathrm{~m}$ 間隔に切つた交点にボーリン グを降ろし,その横断面, 縱断面支図示したのが第7困 である。基礎堤付根附近で浸潤線がセ゚ーク亦した後, 急降下している原因は不明であるが基礎堤内張在石積目 地モルタルにしにのが影響しているのではないかと推定 される。

飽和水点にお打る含水率の状態を第 8 図に示す。含水 率は $20 \%$ から $27.7 \%$ 迄であり，鍍さい放出口附近を中心 にして離れるに従い含水率が大きくなる。また浸涯線も 同傾向を示し，放出口附近が深く，基礎堤に近ずくにし たが、浅くなり，かつ上流に间つて右側が浅くなつてい 亏。

\section{2 安 定計, 算}

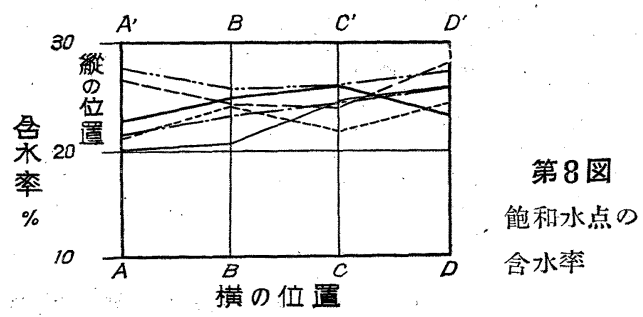



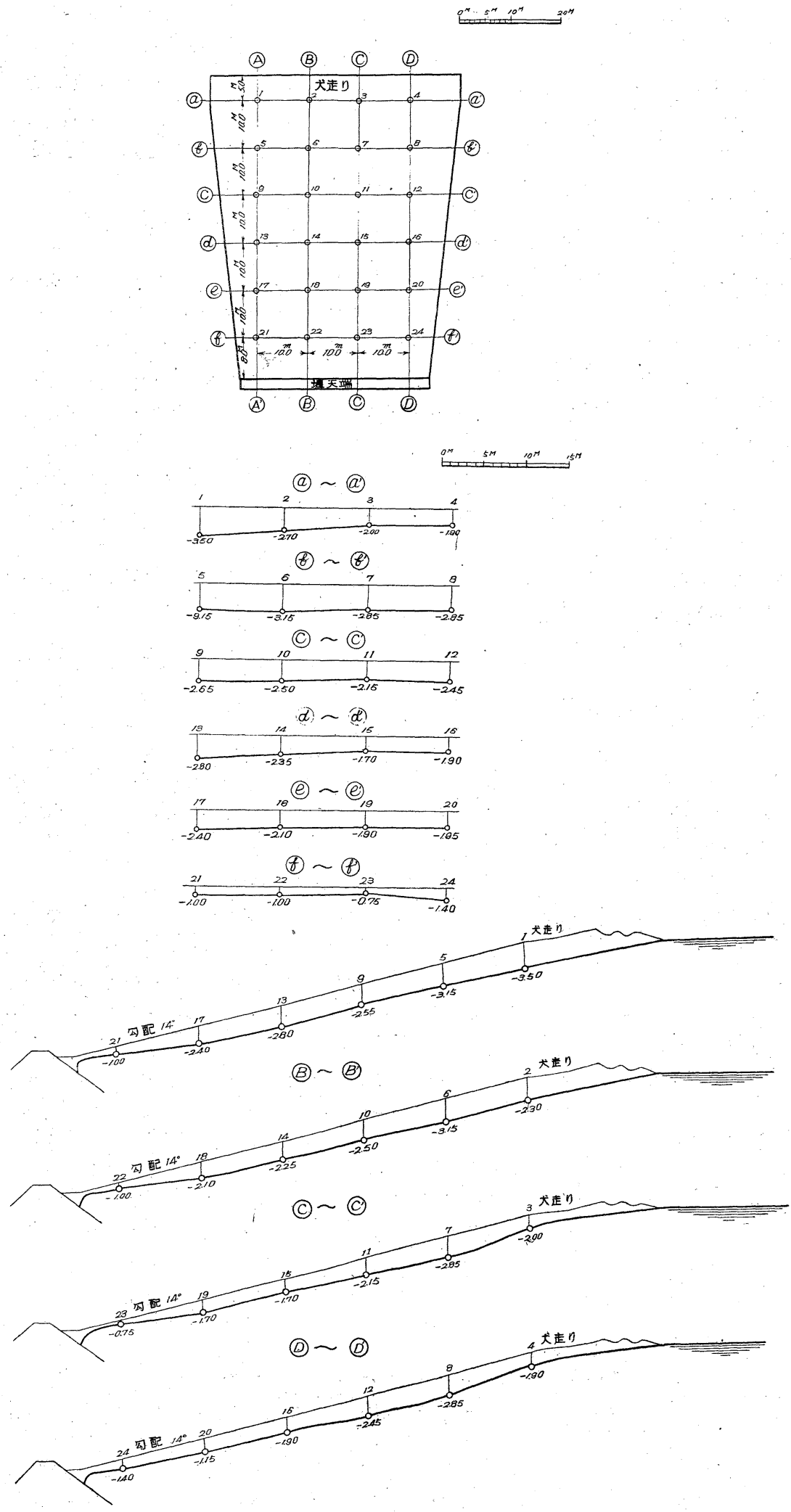

第 7図東沢をい積場浸潤線調查図
たい積試料 2 個につ いて行なつた二面剪断 試験の結果は第 3 表の 通りであり，平均含水 比 $19.87 \%$, 内部摩擦 角 $\theta=26^{\circ}$, 粘着力 $O=$ $0.05 \mathrm{~kg} / \mathrm{cm}^{2}$ そなる。

これらの試験值を基 にして傾斜 $14^{\circ}$, 距離 $50 \mathrm{~m}$ の場合の法面滑 動誩算ば次のようであ る。

$\theta=25^{\circ} 40^{\prime}, C=0.05$ $\mathrm{kg} / \mathrm{cm}^{2}$, 比重 1.7 と乙 円形滑面法により 50 $\mathrm{m}, 40 \mathrm{~m}, 35 \mathrm{~m}, 30 \mathrm{~m}$ の半径な画いた時安全 率は次式で与えられ る。四式佁略守。

$$
\begin{aligned}
& m=\frac{C L+\tan \theta \Sigma N}{\Sigma T} \\
& \text { ただし } m: \text { 安全率 }
\end{aligned}
$$

$L:$ 弧長 $\mathrm{m}$,

$\Sigma N:$ 円弧に囲まれ た部分の土塊 の重量の队弧 の法線方向の 分力の和, $t$

$\Sigma T^{\prime}$ : 円弧に囲まれ た部分の土塊 の重量の切線 方向の分力の 和, $t$

$\theta:$ 内部摩擦角

$C:$ 粘着力

すなわち半径 $40 \mathrm{~m} の$ 堨合滑動面にお污る安 全率洼小になる。

浸涯線を考慮する場 合次式によつて安全率 额計算方る。

$$
\begin{aligned}
& m= \\
& \frac{\sum(N-\mu) \tan \theta+C . L}{\Sigma T} \\
& こ こ に \sum_{\mu}: \text { 間隙水 } \\
& \text { 圧の和, } \mathrm{t}
\end{aligned}
$$$$
\text { 浸涯線は第7 図 C }
$$ 
第3表二面剪断試 験

\begin{tabular}{|c|c|c|c|c|}
\hline \multicolumn{2}{|l|}{ 試 } & \multicolumn{2}{|c|}{ 料 } & \\
\hline \multicolumn{2}{|c|}{ 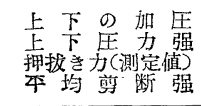 } & \multicolumn{2}{|c|}{$\begin{array}{c}P \mathrm{~kg} / \mathrm{cm}^{2} \\
n \mathrm{~kg} / \mathrm{cm}^{2} \\
F \mathrm{~kg} / \mathrm{cm}^{2} \\
f \mathrm{~kg} / \mathrm{cm}^{2}\end{array}$} & \begin{tabular}{|c|}
20 \\
1,250 \\
32.0 \\
1.00 \\
\end{tabular} \\
\hline \multicolumn{2}{|c|}{$A=$ 剪断面の太さ } & \multicolumn{2}{|c|}{$\begin{array}{l}n=\frac{P}{A}, \\
f=\frac{F}{2 A},\end{array}$} & \\
\hline \multicolumn{5}{|c|}{ 第 4 表 } \\
\hline 滑動牛径m & $\Sigma N$ & $\Sigma T$ & $L$ & $m$ \\
\hline $\begin{array}{l}50 \\
40 \\
35 \\
30\end{array}$ & $\begin{array}{l}406 \\
527 \\
632 \\
816\end{array}$ & $\begin{array}{r}82 \\
118 \\
129 \\
152\end{array}$ & $\begin{array}{l}54.1 \\
56.1 \\
58.0 \\
62.0\end{array}$ & $\begin{array}{l}2.70 \\
2.37 \\
2.57 \\
2.78\end{array}$ \\
\hline
\end{tabular}

No. 1

\begin{tabular}{c|c|c|c|c|c|c|c|c|c|c|c}
20 & 30 & 40 & 50 & 60 & 70 & 20 & 30 & 40 & 50 & 60 & 70 \\
250 & 1,875 & 2,500 & 3,125 & 3,750 & 4,375 & 1,250 & 1,875 & 2,500 & 3,125 & 3,750 & 4,375
\end{tabular}

\begin{tabular}{|l|r|r|r|r|r|r|r|r|r|r|r|r|r|}
\hline 2.0 & 35.0 & 42.0 & 54.0 & 62.0 & 72.0 & 22.5 & 30.5 & 40.0 & 53.0 & 59.0 & 69.0
\end{tabular}

比 $17.64 \%, \theta=260^{\circ}$

$C=0.05 \mathrm{~kg} / \mathrm{cm}^{2}$.

C'色用いて哔算守

ると,

$$
\Sigma \mu=248 \times 1.0=
$$

$248 \mathrm{t}$

安全率最小である滑

動半径 $40 \mathrm{~m}$ をとれば $m=1.37$ となる。故に積み上げた 々積の泿面は傾斜 $14^{\circ}$ ，水平距離 $50 \mathrm{~m}$ ⿸ 1 段として犬走 りにより積上げを連絡しながら，進行せしめることにし た。

\section{3 粒度分子}

廃さい放泥水路に沈積した粒子を水路に沿い，10m間 隔に採取し粒度と含水比を調査したものが第 5 表であ る。

第 5 表 水路の粒度分布

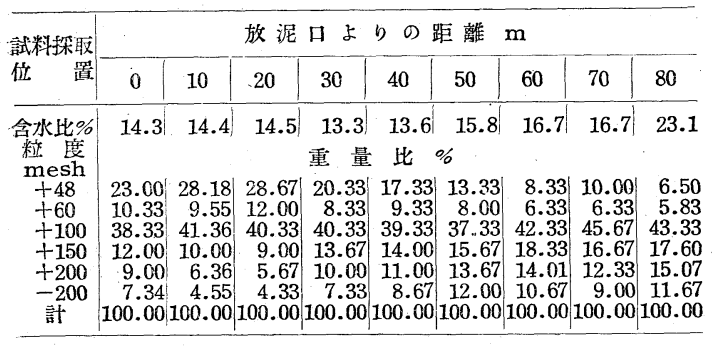

各粒子の沈積比は +150 mesh 以下の細粒は放泥口よ りの距離に正比例し +100 mesh は均等な沈積をなし， +48mesh は反比例しているが各級共沈積比の差は余り 開いていない。放泥口よりの距離と共に細粒の含有率は 幾分高くなるので積み上げたい積の左右両側では強度に 差が出来るものと思われる。また沈積量は放泥口に多く なり勝ちで，積み上げの進行速度は放泥口側が早くなる。 故にこの場合沈積砂の移動も時に必要で，常に谷頭に向 つて直角に積み上げを進行させる様注意す心きである。

\section{8. 経費}

\section{1 起業 費}

たい、積場建設当時より炤和 30 年 7 月までの起業費合計 は9,016,000円 で，7月の工事をもつて本たい積場は所 定垂直高 $50 \mathrm{~m} ， 21,500 \mathrm{t}$ をたい積して満載となる予定で ある。したがって $t$ 当り起業費は約 42 円である。

起業費の支出方年別に挙げると次の通りである。

26年11月 基礎汃ん止堤, 暗渠 $220 \mathrm{~m}$, 沈澱池 2 基
No. 2

5,300,000円

28年 9 月

暗渠延長其他 $130 \mathrm{~m}$ 1,347,000円

30 年 7 月 暗渠延長

$150 \mathrm{~m} \quad 2,369,000$ 円

合䛨 $9,016,000$ 円

\section{2 経 常 費}

たい積場の作業人員は 5 名（男 3 ，女 2 ）で積み上げ 作業，暗渠埋戻及び夜間の監視等たい積全般の作業を行 つている。ただ冬期に積み上げた砂の傾斜補正，真土被 覆には約60工程度の臨時工数が必要である。物品費はも つご, ショベルその他土工用品が小量掛るのみで爷出の 90\%は人件費で占めている。1 万月の平均経常費は工賃 45,637円，物品費 5,021円，合諳 50,658円 で取扱粗鉱 $\mathrm{t}$ 当䄪20円である。

\section{9. 積上げたい積法の特徵}

\section{1 利 点}

a. かん止堤の建設費が少額である

鉱さいたい積場を建設の場合，余程地形に惠まれない 限りかん止堤は非常な高さ存必要とし，建設費の大半は これが築堤のために費さる。本法ではこの点甚だ有利で， 当所の如き狭い地形でもかん止堤の高さは $10.5 \mathrm{~m}$ であ る。たい積閉始後は年 $1 〜 2$ 回側水路, 斜面集水路を延 長し, 暗渠は 2〜3 年の間隔で構築すれればよい。

b. 土地選定が容易である

かん止堤が低くてもよいので設置個所の沢ゆが広くて も差程大きな負担にはならない。また谷に沿つて上部に たい、積が進行して行くので谷の傾斜が積上げの傾斜以下 であれば谷の続くかきり積み上げを上昇させる事が出来 る。沢でなくとも山の麓に基礎堤る築き，山の斜面に沿 つて積み上げて行く事も不可能ではない。

\section{c. 導水路中でスラィムの自然分粒が行われる}

この結果堤体の前面に粗粒の砂が集まり, 理想的な砂 かん止堤が出来上り，機械的に分粒を行つて砂たい積を する必要がない。また水路面と場内水面は $1 \mathrm{~m}$ 以上の上 下間隔があり，水路部分の川゙は 2 本合計すると $10 \mathrm{~m}$ ある ので場内水がたい積部に接近する事がなく，普通の蒿揚 法に比較して場内水のためにたい積部が浸蝕される乍険 性が少ない。

\section{d. たい積の監視支び充分な管理が行われる}

常時作業員を配置し, 毎日少しづつたい積して行くの で堤体の構築に充分な監視之管理が行われ，濁水の流失 等の事は起り難く，夜中の事故等す未然に防止出来る。

\section{2 欠 点}

a. 経常費がかかる 
建設費が少なくてすむかわりに，常に作業員を配置し また年 1,2 回の側水路，斜面集水路抢よび法面保護の工 事費在必要之李るので経常費が堌額する。

b. 場内水及び沢水の排除は充分に行わねぱならない

たい積物が廃さい砂なので真土に比べ粘着力が弱く， 強度が劣方ので場内水及び沢水の排除には特に注意し， 溜水が出来ない様にしなければならない。また天候気温 によつても浸潤線が影響を受けるので，たい積面は水分 の蒸発し易い状態に保つことが必要である。

c. 法面保護用の土が必要

堆積物を雨水の流失から防ぐため真土被覆が必要とな るので堆積場附近に山士採取の出来易い場所がなければ

ならない。

10. 結語

本積上げたい積を始めてから4年を経過し設計変更， 冬期の作業等色々な曲節はあつたが，現在は安全度，作 業共に安定状態にある。乙かし今後積み上げの進行に伴 い間㗂水圧の変化とたい積内部でサンドとスライムがき の様な状態で分布しているか等，将来に残された問題が 多い。この点本報文は未熟なものであるが，今後本方式 を採用される現場で何かの参考になれば望外の幸いであ る。なお本法施行に当り 2,5 年に亘り現塓監督として尽 瘁した元鯛生金山勤務松尾卯三郎君の功績を謝す。

\section{製品紹介}

\section{ドルコーフルォソリッド焙燒裝置}

流体の上昇流中に固体粒子を浮遊させながら化学反応 や物理的変化を行わせる Fluidization 法を焙焼に分用 して工業的成功を収めたのが Fluo-Solids Roaster で ある。この画期的な方式は，鉄・銅・亚 鉿・コバル下・金・クローム・粼鉣石・石 灰石等の鉱吕の焙焼処理に適用されて成功 を収めている。また硫化鉄鉣・磁硫鉄鉣の 然焼による亜硫酸方え発生に利用されてお りすでに 80 㶤が世界全般にわだり稼動 している。わが国でも同和鉣業・三菱金属 の両社で銅あるいは覀鉛釷の製錬に採用し ている。またこの装置によつて微粉状の鉣

\begin{tabular}{|c|c|c|c|}
\hline & 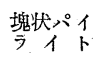 & 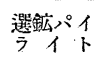 & $\begin{array}{l}\text { 贪銅パイ } \\
\text { イ }\end{array}$ \\
\hline 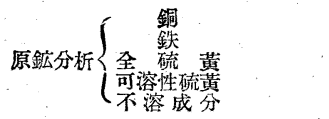 & $\begin{array}{r}42.5 \\
48.3 \\
0.3 \\
4.8\end{array}$ & $\begin{array}{r}45.6 \\
49.4 \\
0.6 \\
\ldots\end{array}$ & $\begin{array}{c}13.3 \\
34.6 \\
40.0 \\
0.3 \\
\cdots\end{array}$ \\
\hline $\begin{array}{cc}\text { 節 分 析 } & +14 \\
& +20 \\
& +28 \\
& +35 \\
& +48 \\
& +65 \\
& +100 \\
& +150 \\
& +200\end{array}$ & $\begin{array}{r}3.2 \\
23.5 \\
43.7 \\
57.4 \\
68.6 \\
78.0 \\
85.0 \\
90.6 \\
93.5\end{array}$ & 全通 & 全通 \\
\hline 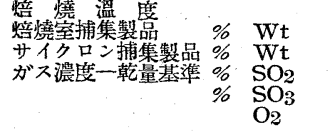 & $\begin{array}{l}900^{\circ} \mathrm{C} \\
70.4 \\
29.6 \\
14.3 \\
\operatorname{tr} \\
0.1\end{array}$ & $\begin{array}{l}700^{\circ} \mathrm{C} \\
49.8 \\
50.2 \\
16.2 \\
\operatorname{tr} \\
\ldots\end{array}$ & $\begin{array}{l}700^{\circ} \mathrm{C} \\
47.7 \\
52.3 \\
7.0 \\
\cdots \\
3.0\end{array}$ \\
\hline 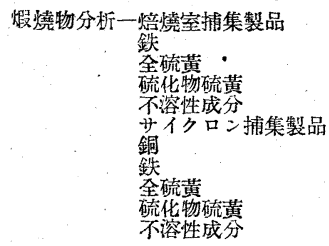 & $\begin{array}{r}16.9 \\
0.42 \\
0.32 \\
29.5 \\
\\
69.4 \\
0.42 \\
0.09 \\
3.5\end{array}$ & $\begin{array}{l}70.6 \\
0.75 \\
0.25 \\
0.71 \\
\\
69.4 \\
1.1 \\
0.33 \\
0.58\end{array}$ & \\
\hline
\end{tabular}

石の任意温度による乾燥が行われる。

本機の特徽としては次のようなことが挙げられる。 （1）炉内心゙ッドの焙焼温度の均一（2） 反応温度 の保持が容易 (3) 発生ガンの調節が可能 (4) 燃料の節約 （5）維持費が少ない（6）操作が籀 単である。

（三機工業ドル機械部提供）

\begin{tabular}{|c|c|c|c|c|c|}
\hline 含銅パイライト & \multicolumn{2}{|c|}{ 水溶性分 } & \multicolumn{3}{|c|}{$5 \% \mathrm{H}_{2} \mathrm{SO}_{4}$ 可溶性分 } \\
\hline 椵燒物 & 残㵏 & 可溶性分\% & 煆燒物 & 残滓 & 可溶性分\% \\
\hline \multicolumn{6}{|l|}{ 焙燒室捕集製品 } \\
\hline 銅 29.2 & 2.6 & 91.5 & 31.1 & 0.9 & 97.3 \\
\hline 鉄 0.6 & 58.2 & 1.0 & 1.4 & 61.2 & 2.3 \\
\hline \multicolumn{6}{|l|}{ サイクロン捕集製品 } \\
\hline 銅 19.6 & 2.2 & 87.2 & 20.8 & 1.3 & 92.7 \\
\hline 铁 0.35 & 62.3 & 0.4 & 1.2 & 63.6 & 1.5 \\
\hline \multirow[t]{2}{*}{ 全溶解度 } & 90.2 & & & & \\
\hline & 可溶㭌 & 95.2 & & & \\
\hline
\end{tabular}

詩：上表は Mining Congress J., Mar. 1951 より なお $\mathrm{SO} 2$ gas 発生学目的にした場合 $46 \% \mathrm{~S}$ 程度の pyriteに。 対する Reactor Area・の大略は給鉱 Dry basis ton/dayに 対して 2.5 3.0口 である。 